\title{
Writing as a Tool for Constructive Rehabilitation Susan Nagelsen
}

$\mathrm{T}$ he relative paucity of academic discussion concerning the education of state and federal prisoners in the United States can be traced to a large extent to the tendency of scholars to subsume education within the more general rubric of programming. This is not to say that education is not recognized as an important, even vital element in addressing prisoners' abilities to develop and maintain skill sets that will enable them to return to society and remain there as productive members. Indeed, studies have shown that recidivism rates inversely correlate with levels of education (Nagelsen, 2004). The specifics of the process itself however, the manner in which educational programs are designed, funded and made available to prison populations, remains one of the least examined areas in related disciplines.

The situation is exacerbated by fiscal constraints, often imposed by legislatures and prison administrations that routinely eliminate any program or service that could remotely be construed as "coddling" prisoners, especially when the subject is framed as a zero-sum proposition that posits opportunities for prisoners as antagonistic to those of society. As Johnson (2003) describes the attitude, "[n]othing constructive could be done for prisoners". Pell Grants for prisoners were rescinded in 1994 for precisely this reason and this left prisoners, often wards of the state, at the mercy of those who incarcerate them for their rehabilitation. The passing of time has only served to aggravate the problem as a look at the recent data shows that educational programs in prisons across the country have been gutted, and prisoners that I speak to regularly tell me that they are spending more and more time locked in their cells with little to do.

If few educational programs exist to provide statistical reliability, then academic discussions of their philosophical significance and their existential relevance remain speculative. Given these institutionalized failures, research into the intellectual development of prisoners, leaves only one option, the writing produced by the prisoners themselves.

While teaching in a postsecondary program at New Hampshire State Prison for Men in Concord, I validated how writing relates to - and has an impact on - the cognitive development of the particular writer. It was particularly evident in the prison environment because the men and women spend so much time isolated from the real world. My introduction to the Journal of Prisoners on Prisons affirmed the connection between that development and the structured, written expression of thought as an 
indicator of an evolutionary process, both social and academic (Nagelsen and Huckelbury, 2007). My experiences eventually led to a project that took me to prisons across the United States to interview prisoners whose work had been chosen for publication in a book dealing with prison issues and incarcerated writers. Each of the writers had vast experience with prison and the use of writing as a tool for sanity, for healing and for building autonomy in a world where little exists. The contributors had also previously won a PEN Prison Writing Award. As the subsequent book illustrates, the men and women who write from prison often demonstrate an astonishing potential that could benefit from a structured learning environment, one that concomitantly validates their self-worth, and directs and encourages a talent that could be of practical benefit (Nagelsen, 2008).

Any serious study of education inside prisons today must therefore include a close reading of the written work produced by the prisoners themselves, frequently self-directed but always an expression of personal growth. A warning however is in order, as Johnson (2002: 294) reminds us: "[ $\mathrm{t}] \mathrm{o}$ compete for the attention of prisoners, programs must appeal to their self-interest in direct and immediate ways". Writing does precisely that, which is why it can at least partially serve the same laboratory function as the classroom.

By putting pen to paper, prisoners find an immediate route to selfexpression. Editorial feedback, whether from the staff at the JPP or in mainstream periodicals, validates their work and brings them into contact with men and women on the outside. By allowing this form of self-directed exploration, both educational achievement and social fluency advance, contrary to the resentment often fostered when tedious or boring programming is forced by staff "recommendations" or viewed only as a means to an end. Writing is an educational experience that continues to provide benefits beyond the classroom.

In the current climate of rising costs and political animus, writing by prisoners becomes in large measure the only available vehicle to counter the stultifying existence they encounter daily. Education and writing in particular, opens the doors to a closed world, providing prisoners with voices that have previously been silenced. The academic discourse around the necessity for educational programs in prisons should be of vital concern. It is in the best interest of prisoners and the community that we educate men and women who will be returned to society so that they can contribute in productive and meaningful ways. 


\title{
REFERENCES
}

Johnson, Robert (2002) Hard Time: Understanding and Reforming the Prison, Belmont (CA): Wadsworth/Thomson Learning.

Nagelsen, Susan (ed.) (2008) Exiled Voices, Portals of Discovery, Henniker (NH): New England College Press.

Nagelsen, Susan (2004) "What Have We Got to Lose?", Journal of Prisoners on Prisons, 13: 133-139.

Nagelsen, Susan and Charles Huckelbury (2007) "A Conversation", Journal of Prisoners on Prisons, 16(2): 113-118.

\begin{abstract}
About the Author
Susan Nagelsen is Director of the Writing Program at New England College in Henniker, New Hampshire, where she has taught for twentyfour years. She is an essayist and a fiction writer as well as the author of two writing manuals. She teaches first-year courses as well as advanced essay writing courses such as the art of the essay and content based writing. She also teaches in the Criminal Justice program where her course focuses on teaching students about prison from the point of view of prisoners. Her most recent published fiction can be found in the fall 2005 edition of the Henniker Review, Tacenda, Bleakhouse Review and in the Journal of Prisoners on Prison Volume 14(2), an issue addressing aging in prison. She is a frequent contributor to the $J P P$ and is currently Associate Editor. Susan is the editor of an anthology of work by incarcerated writers entitled Exiled Voices, Portals of Discovery (2008) published by New England College Press. The book features thirteen incarcerated writers with an introduction to each written by Nagelsen and is being used as a textbook in courses focusing on criminal justice issues.
\end{abstract}

